International Journal of Educational Administration, Management, and Leadership

P R R R S S S

ISSN (Print): 2580-1309

\title{
The Effect of Private Visiting and Promotion Strategy on Tourist Interest Visiting in Bali City
}

\author{
Wayan Ardani ${ }^{1}$, Ashfaq Hossain Khan ${ }^{2}$, Iis Noviyanti ${ }^{3}$, Mohammad Farhan Zeb \\ $\mathrm{Khan}^{4}$ \\ ${ }^{1}$ Universitas Mahendradatta, Denpasar, Bali, Indonesia \\ ${ }^{2}$ Inti International College Subang, Southern New Hampshire University, Malaysia \\ ${ }^{3}$ Universitas Pamulang, Tangerang Selatan, Banten, Indonesia \\ ${ }^{4}$ Jawaharlal Nehru University New Delhi, India \\ E-mail: ardani.shuarsedana@gmail.com
}

(Received: February-2020; Reviewed: March-2020; Accepted: April-2020;

Avalaibel Online: May-2020; Published: May-2020)

\begin{abstract}
This study aims to determine the effect of tour guides and promotional strategies on the interest of tourists visiting Bali. The method used is explanatory research with analysis techniques using statistical analysis with regression testing, correlation, determination and hypothesis testing. The results of this study that the guide has a significant effect on tourist interest by $43.2 \%$, hypothesis testing is obtained $t$ count $>\mathrm{t}$ table or $(8,452>1.986)$. Promotion strategy has a significant effect on tourist interest by $43.9 \%$, hypothesis testing is obtained $t$ count $>t$ table or $(8,576>1,986)$. Tour guides and promotion strategies simultaneously have a significant effect on tourist interest with the regression equation $\mathrm{Y}=9.311+0.372 \mathrm{X} 1+0.406 \mathrm{X} 2$. The contribution of the effect was $53.7 \%$, the hypothesis test obtained F count $>\mathrm{F}$ table or $(53.950>2,700)$.
\end{abstract}

Keywords: Tour Guide; Promotion Strategy; Tourist Interest.

\section{INTRODUCTION}

The development of tourism in Indonesia is growing rapidly. Various regions compete to show the various advantages of their regions. Various tourist attractions generally contain typical values of an area (Houge Mackenzie et al., 2020; Huerta-Álvarez et al., 2020; Husain et al., 2018a, 2018b). There are various kinds of tourist objects that exist with their various uniqueness. According to Pan et al., (2020) a tourist attraction is something that becomes the center of tourist attraction and can provide satisfaction to tourists. The existence of a tourism object, the main problem arises, namely how to utilize tourism which is able to stimulate the development of the environment and society properly and prevent adverse effects or consequences. 
The meaning of the word tourism has not been widely expressed by Indonesian language and tourism experts (Gao et al., 2012; Grissemann \& Stokburger-Sauer, 2012; Papalapu et al., 2016; Said et al., 2017). the word tourism comes from two syllables, namely pari and tourism. Pari means many, many times and circling, while tourism means traveling or traveling. So, tourism means travel or traveling that is done many times or around. Tourism is the equivalent of the term tourism in English. The definition of tourism according to Law Number 10 of 2009, tourism is a variety of tourist activities and is supported by various facilities and services provided by the community, businessmen, government and local governments.

Tourism today is full of competition. One Tourist Destination Area (DTW) always tries to attract more tourists than other DTWs, to be able to win the competition not only by promotion, but what is important is to provide good service, namely services that can satisfy tourists visiting the DTW (Malenkina \& Ivanov, 2018). Excellent service can only be provided by professional tour guides, namely those who are always oriented towards tourist satisfaction. In order to become a professional tour guide, apart from having experience, you must always have the ability, both theoretically and technically, in providing services to tourists in general. In addition, a tour guide must also have knowledge that is supported by the ability and selfconfidence to face routine and changing tasks (Houge Mackenzie et al., 2020).

In everyday life, people are more familiar with the term guide than guide. Everyone who accompanies and accompanies tourists, visits tourism objects, watches shows, etc. is always connoted as a guide. According to Yoeti (2010), a tour guide is a person in charge of providing guidance, information and guidance about attractions or destinations. A tour guide must be able to give pleasure or satisfaction to everything he brings. Therefore, to find out the desires and tastes of tourists, a tour guide should combine his knowledge, skills, and feelings in order to achieve the pleasure desired by the tourists he brings.

Tourism will not develop if other people are reluctant to visit because they are blind to the information about tourism. Therefore we need various tourism promotions. Promotion itself is an attempt to increase the attractiveness of a tourist attraction to potential tourists. Tourists and their needs are not handled, but the tourist products are more tailored to the demands of tourists (Gao et al., 2012; Grissemann \& Stokburger-Sauer, 2012; Muhtasom et al., 2019; Pan et al., 2020; Said et al., 2017). Promotion is an activity that mainly includes distributing promotional materials, such as films, slides, advertisements, brochures, booklets, leaflets, folders, through various kinds. channels (channels) such as: TV, radio, magazines, cinemas, direct-mail both for potential tourists, namely a number of people who meet the minimum requirements for travel, because they have a lot of money, their physical condition is still strong, but they don't have free time traveling as tourists or actual tourists, namely people who are on a tourism trip to a certain destination; with the aim of transferring information and influencing potential tourists to visit a tourist destination.

Tourists are an inseparable part of the world of tourism. Tourists are very diverse, all of whom have different desires and expectations. When viewed from the meaning of the word tourist which comes from the word tourism, it is actually not an appropriate substitute for the word tourist in English. The word comes from the Sanskrit word for tourism which means the same trip or can be equated with the word travel in English. So when people travel in this sense, tourists have the same meaning as the word traveler because in Indonesian it is customary to use the suffix wan to describe people with their profession, expertise, position of position and one's position (Said et al., 2017).

The city of Bali is one of the major cities in Indonesia which is one of the biggest cities in Indonesia. 


\section{METHOD}

Population is a set of objects that are determined through certain criteria which will be categorized into the object to be studied. According to Creswell \& Creswell (2017)defining population is the number of generalization areas consisting of objects or subjects that have the qualities and characteristics set by the researcher and then draw conclusions. The population in the study amounted to 96 respondents according to Creswell \& Clark (2017), namely "The sample is the number and characteristics of the population". Meanwhile, Creswell \& Clark (2017) argues that "The sample is part or representative of the population under study". The sampling technique in this research is saturated sample, where all members of the population are sampled. Thus the sample in this study amounted to 96 respondents. This type of research used is associative, where the aim is to find out the relationship between. In analyzing the data used instrument test, classical assumption test, regression, coefficient of determination and hypothesis testing.

\section{RESULT AND DISCUSSION}

\section{Test Intruments}

In this test used the validity test and reliability test. The validity test is intended to determine the accuracy of the data regarding the suitability between what is being measured and the measurement results. According to Sugiyono (2016) "Valid means that there is a similarity between the collected data and the real data". Meanwhile, Ghozali (2013) argues that "A questionnaire is said to be valid if the questions on the questionnaire are able to reveal something that will be measured by the questionnaire." To test the validity, the 2 tailed significance value is seen compared to 0.05 provided that:

1) If the 2 stringed significance value $<0.05$, then the instrument is valid,

2 ) If the 2 stringed significance value $>0.05$, then the instrument is invalid,

From the test results, it is obtained that each item statement for all variables obtained a 2 tailed significance value of $0.000<0.05$, thus the instrument is valid. The next test is the reliability union. The reliability test analysis model used in this study is the Alpha Cronbach model. According to Ghozali (2013), "reliability is a tool for testing the consistency of respondents' answers to the questions in the questionnaire. A questionnaire is said to be reliable if a person's answer to a question is consistent or stable over time ". The measurement is done by using Cronbach's Alpha analysis. Ghozali (2013) classifies the value of Cronbach's Alpha as follows: 1) 1) If the value of Cronbach's Alpha> 0.60, it is declared reliable, and 2) If the value of Cronbach's Alpha <0.60, it is declared unreliable, The test results are presented in table 1.

Table 1. Reliability Testing

\begin{tabular}{lccc}
\hline \multicolumn{1}{c}{ Variable } & Cronbach's Alpha & Alpha Critical Standard & Information \\
\hline Tour guide (X1) & 0,722 & 0,600 & Reliabel \\
Promotion strategy (X2) & 0,673 & 0,600 & Reliabel \\
Tourist interest (Y) & 0,690 & 0,600 & Reliabel \\
\hline
\end{tabular}

Based on the above test results, the overall guide variable (X1), promotion strategy (X2) obtained a Cronbach alpha value greater than 0.60 . Thus it is declared reliable.

\section{Classic assumption test}


The classical assumption test is intended to determine the accuracy of a data. According to Singgih Santoso (2011) "A regression model will be used to make forecasts, a good model is a model with minimal forecast errors". Therefore, a model before it is used should satisfy several assumptions, which are commonly called classical assumptions. In this study, the classical assumption tests used were: Normality Test, Multicollinearity Test, Autocorrelation Test, and Heteroscedasticity Test. The results are as follows:

\section{Normality test}

The normality test is carried out to test whether the regression model, the dependent variable and the independent variable are normally distributed or not. The results of the normality test using the Kolmogorov-Smirnov Test are at Table 2.

Table 2. Results of Kolmogorov-Smirnov Normality

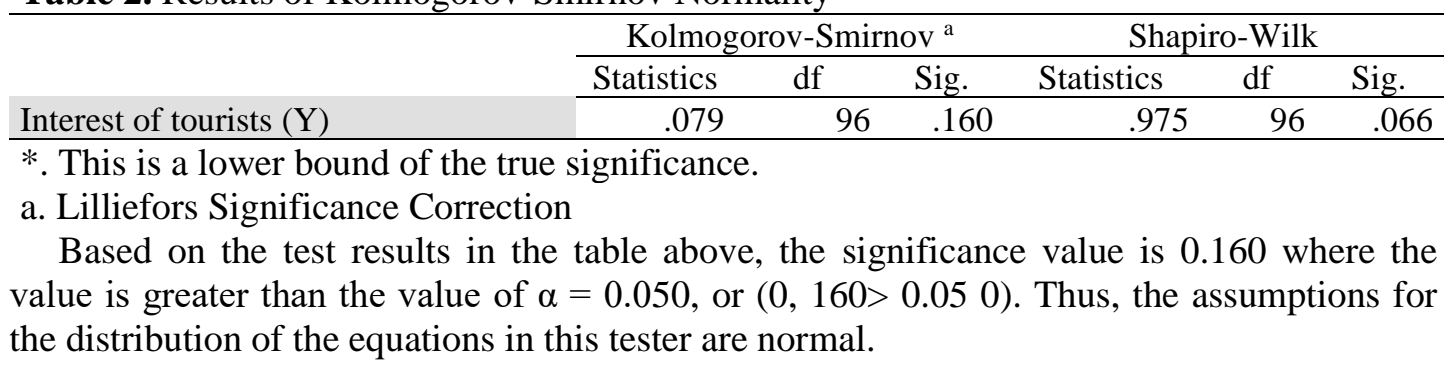

\section{Multiconilierity Test}

Mutlycolinearity testing is conducted to ensure that the independent variables do not have multicollinearity or do not have a correlation effect between the variables that are determined as models in the study. The multicollinearity test is carried out by looking at the Tolerance Value and Variance Inflation Factor (VIF). The test results are presented in table 3.

Table 3. Multicollinearity Test Results with Collinierity Statistic.

\begin{tabular}{|c|c|c|c|c|c|c|}
\hline & \multirow{3}{*}{ Model } & \multicolumn{5}{|c|}{ Coefficients a } \\
\hline & & \multicolumn{2}{|c|}{$\begin{array}{l}\text { Unstandardized } \\
\text { Coefficients }\end{array}$} & \multirow{2}{*}{$\begin{array}{c}\begin{array}{l}\text { Standardized } \\
\text { Coefficients }\end{array} \\
\text { Beta } \\
\end{array}$} & \multicolumn{2}{|c|}{$\begin{array}{c}\text { Collinearity } \\
\text { Statistics }\end{array}$} \\
\hline & & B & Std. Error & & Tolerance & VIF \\
\hline \multirow[t]{3}{*}{1} & (Constant) & 9,311 & 2,890 & & & \\
\hline & Tour Guide (X1) & .372 & .084 & .505 & .614 & 1,629 \\
\hline & Promotion strategy (X2) & .406 & 088 & .370 & .614 & 1,629 \\
\hline
\end{tabular}

a. Dependent Variable: Tourist interest (Y)

Based on the test results in the table above the value of tolerance of each independent variable is $0,614<1.0$ and a value Variance Inflation Factor (VIF) of $1,629<10 \mathrm{~d}$ ith so this does not happen regression model multikolinearitas.

\section{Autocorrelation Test}

Autocorrelation testing is used to determine whether or not there are correlation deviations between sample members. The test was carried out with the Darbin-Watson test $(D W$ test $)$. The test results are presented in table 4 . 
Tabel 4. Autocorrelation Test Results

\begin{tabular}{ll|r|r|r|r}
\multicolumn{7}{c}{ Model Summary $^{\mathbf{b}}$} \\
\hline Model & $\mathrm{R}$ & \multicolumn{1}{c}{ R Square } & $\begin{array}{c}\text { Adjusted R } \\
\text { Square }\end{array}$ & $\begin{array}{l}\text { Std. Error of } \\
\text { the Estimate }\end{array}$ & Durbin-Watson \\
\hline 1 & $.733^{\mathrm{a}}$ & .537 & .527 & 2,465 & 1,972 \\
\hline
\end{tabular}

a. Predictors: (Constant), Promotion strategy (X2), Tour Guide (X1)

b. Dependent Variable: Tourist interest (Y)

Testing the results in table 4 shows that the Durbin-Watson value of 1, 992 is between the scores of 1550-2460. With a regression model that states there is no autocorrelation disorder.

\section{Heteroskesdasticity test}

Heteroscedasticity testing is intended to test whether in a regression model there is an inequality of residual variance. The test results are presented in table 5.

Table 5. Heteroskesdasticity Test Results with Glejser Test Model

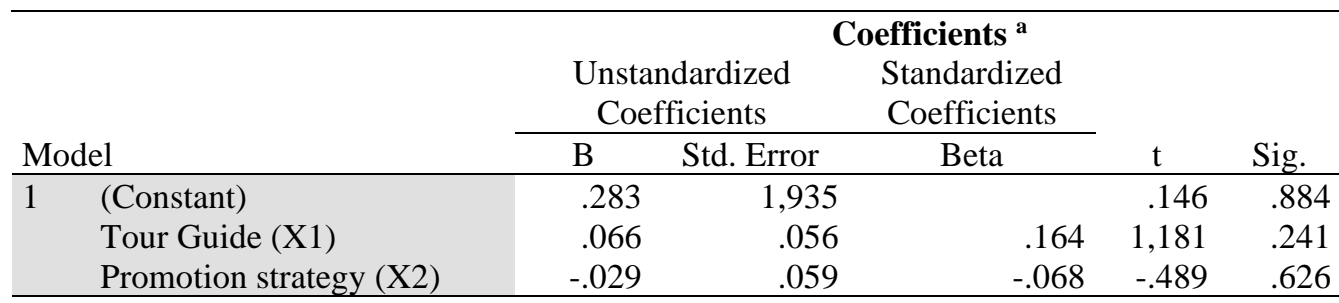

a. Dependent Variable: RES2

The test results using the Glejser test obtained the value of $\mathrm{S}$ ig. $>0.05$. Thus the regression model does not have heteroskesdasticity disorder.

\section{Descriptive Analysis}

In this test, it is used to determine the minimum and maximum score, mean score and standard deviation of each variable. The results can be seen in table 6 .

Table 6. Descriptive Statistics Analysis Results Table

\begin{tabular}{lrrrrr}
\hline & \multicolumn{5}{c}{ Descriptive Statistics } \\
\cline { 2 - 6 } & \multicolumn{1}{c}{ N } & Minimum & Maximum & Mean & Std. Deviation \\
\hline Tour Guide (X1) & 96 & 32 & 48 & 38.43 & 3,849 \\
Promotion strategy (X2) & 96 & 30 & 45 & 38.40 & 3,661 \\
Interest of tourists (Y) & 96 & 32 & 46 & 39.19 & 3,585 \\
Valid N (listwise) & 96 & & & &
\end{tabular}

Guides obtained variance minimum of 32 and a variance of maximum 48 with $a$ mean score of 3,8 43 with s tandar deviation of 3,849. Promotion strategy obtained the variance minimum of 30 and variance maximum 45 with a mean score of 3,840 with a standard deviation of 3,661. Traveler interest earned variance minimum of 32 and a variance of maximum 46 with a mean score of 3,919 with a standard deviation of 3, 585 . 


\section{Verificative analysis}

This analysis aims to determine the effect of the independent variable on the dependent variable.

\section{Multiple Linear Regression Analysis}

This regression test is intended to determine changes in the dependent variable if the independent variable changes. The test results are presented in table 7.

Table 7. Results of Regression Testing Lin i er Regression

\begin{tabular}{llrrrrr}
\multicolumn{1}{c}{ Model } & \multicolumn{2}{c}{ Coefficients $^{\text {a }}$} \\
& \multicolumn{2}{c}{$\begin{array}{c}\text { Unstandardized } \\
\text { Coefficients }\end{array}$} & $\begin{array}{c}\text { Standardized } \\
\text { Coefficients }\end{array}$ & t & \multirow{2}{*}{ Sig. } \\
\cline { 3 - 5 } & \multicolumn{1}{c}{ B } & Std. Error & Beta & & \\
\hline \multirow{2}{*}{1} & (Constant) & 9,311 & 2,890 & & 3,222 & .002 \\
& Tour Guide (X1) & .372 & .084 & .400 & 4,440 & .000 \\
& Promotion strategy (X2) & .406 & .088 & .414 & 4,599 & .000 \\
\hline
\end{tabular}

Based on the test results in the table above, the regression equation $\mathrm{Y}=9.311+0.372 \mathrm{X} 1$ $+0.406 \mathrm{X} 2$ is obtained. From this equation it is explained as follows:

1) A constant of 9.311 means that if the tour guide and promotion strategy do not exist, there is already a tourist interest value of 9.311 points.

2) The regression coefficient guides at 0.372 , this figure is positive it means that whenever there is an increase in the guide by 0.372 then the tourists will be increased by 0.372 points.

3) The regression coefficient promotion strategy of 0.406 , this figure is positive it means that whenever there is an increase in the promotion strategy of 0.406 then the tourists will be increased by 0.406 points.

\section{Correlation Coefficient Analysis}

Correlation coefficient analysis is intended to determine the level of strength of the relationship between the independent variable and the dependent variable either partially or simultaneously. The test results are presented in table 8.

Table 8. Testing Results Correlation Coefficient Guides Against the Interests travelers .

\begin{tabular}{|c|c|c|c|}
\hline \multicolumn{4}{|c|}{ Correlations $^{\text {b }}$} \\
\hline & & $\begin{array}{c}\text { Tour } \\
\text { Guide (X1) }\end{array}$ & Interest of tourists (Y) \\
\hline \multirow[t]{2}{*}{ Tour Guide (X1) } & Pearson Correlation & 1 & $.657^{* *}$ \\
\hline & Sig. (2-tailed) & & .000 \\
\hline \multirow[t]{2}{*}{ Interest of tourists (Y) } & Pearson Correlation & $.657^{* *}$ & 1 \\
\hline & Sig. (2-tailed) & .000 & \\
\hline
\end{tabular}

Based on the test results obtained a correlation value of 0.657 means that the tour guide has a strong relationship with tourist interest. 
Table 9. Correlation Coefficient Testing Results of Promotion Strategies Against Tourist Interest.

\begin{tabular}{llrrr}
\multicolumn{4}{c}{ Correlations $^{\mathbf{b}}$} \\
\hline & \multicolumn{2}{c}{ Promotion strategy (X2) } & \multicolumn{1}{c}{ Interest of tourists (Y) } \\
\hline $\begin{array}{l}\text { Promotion } \\
\text { strategy (X2) }\end{array}$ & Pearson Correlation & 1 & $.657^{* *}$ \\
\cline { 2 - 4 } $\begin{array}{l}\text { Interest of } \\
\text { tourists (Y) }\end{array}$ & Pearson Correlation & Sig. (2-tailed) & $.657^{* *}$ & .000 \\
\cline { 2 - 4 } & Sig. & .000 & 1 \\
\hline
\end{tabular}

Based on the test results obtained a correlation value of 0.657 means that the promotion strategy has a strong relationship with tourist interest .

Table 10. The Result of Testing the Correlation Coefficient of Guides and Promotion Strategies simultaneously on Tourist Interest .

Model Summary

\begin{tabular}{lrr|r|r}
\hline Model & R & \multicolumn{1}{c|}{ R Square } & Adjusted R Square & Std. Error of the Estimate \\
\hline 1 & $.733^{\mathrm{a}}$ & .537 & .527 & 2,465 \\
\hline
\end{tabular}

a. Predictors: (Constant), Promotion strategy (X2), Tour Guide (X1)

Based on the test results obtained a correlation value of 0.733 means that the tour guide and promotion strategy simultaneously have a strong relationship with tourist interest .

\section{Analysis of the coefficient of determination}

Analysis of the coefficient of determination is intended to determine the percentage of influence of the independent variable on the dependent variable either partially or simultaneously. The test results are as follows:

Table 11. Results of Testing the Coefficient of Determination of Tourists on Tourist Interest Model Summary

\begin{tabular}{|c|c|c|c|c|}
\hline Model & $\mathrm{R}$ & R Square & Adjusted R Square & Std. Error of the Estimate \\
\hline$\overline{1}$ & $.657^{\mathrm{a}}$ & .432 & .426 & 2,716 \\
\hline
\end{tabular}

Based on the test results obtained a determination value of 0.432 means that the tour guide has an influence contribution of $43.2 \%$ on tourist interest.

Table 13 Results of Testing the Coefficient of Determination of Promotion Strategies on Tourist Interest.

\begin{tabular}{lr|rrrr}
\multicolumn{6}{c}{ Model Summary } \\
\hline Model & R & \multicolumn{2}{c}{ R Square } & Adjusted R Square & \multicolumn{1}{c}{ Std. Error of the Estimate } \\
\hline 1 & $.663^{\text {a }}$ & .439 & .433 & 2,699 \\
\hline
\end{tabular}

a. Predictors: (Constant), Promotion strategy (X2)

Based on the test results obtained by the value of determination of 0.439 means a promotion strategy has contributed influence of $43.9 \%$ against the interest of tourists .

Table 14. Coefficient Determination Test Result Guides and promotion strategy Against the Interests travelers .

\begin{tabular}{|c|c|c|c|c|}
\hline \multicolumn{5}{|c|}{ Model Summary } \\
\hline Model & $\mathrm{R}$ & R Square & Adjusted R Square & Std. Error of the Estimate \\
\hline 1 & $.733^{\mathrm{a}}$ & .537 & .527 & 2,465 \\
\hline
\end{tabular}


of $53.7 \%$ against the interest of tourists, while the remaining $46.3 \%$ influenced by other factors.

\section{Hypothesis testing}

a. Partial hypothesis test ( $t$ test)

Hypothesis testing with the $t$ test is used to determine which partial hypothesis is accepted. The first hypothesis: There is a significant influence between tour guides on tourist interest.

Table 15 Hypothesis Test Results for Guide Tourists on Tourist Interest .

\begin{tabular}{|c|c|c|c|c|c|c|}
\hline \multirow[b]{3}{*}{ Model } & \multirow{2}{*}{\multicolumn{2}{|c|}{$\begin{array}{c}\text { Unstandardized } \\
\text { Coefficients }\end{array}$}} & \multirow{3}{*}{\multicolumn{2}{|c|}{$\begin{array}{c}\text { Standardized } \\
\text { Coefficients } \\
\text { Beta }\end{array}$}} & \multirow[b]{3}{*}{$\mathrm{t}$} & \multirow[b]{3}{*}{ Sig. } \\
\hline & & & & & & \\
\hline & B & Std. Error & & & & \\
\hline 1 (Constant) & 15,672 & 2,796 & & & 5,605 & .000 \\
\hline Tour Guide (X1) & .612 & .072 & & .657 & 8,452 & .000 \\
\hline
\end{tabular}

a. Dependent Variable: Tourist interest (Y)

Based on the test results in the table above, the value of $t$ count $>t$ table or $(8.452>1.986)$, so the first hypothesis proposed that there is a significant effect only between the guides to tourists received.

Table 16. Hypothesis Test Results of Promotion Strategies Against Tourist Interest .

Coefficients $^{\text {a }}$

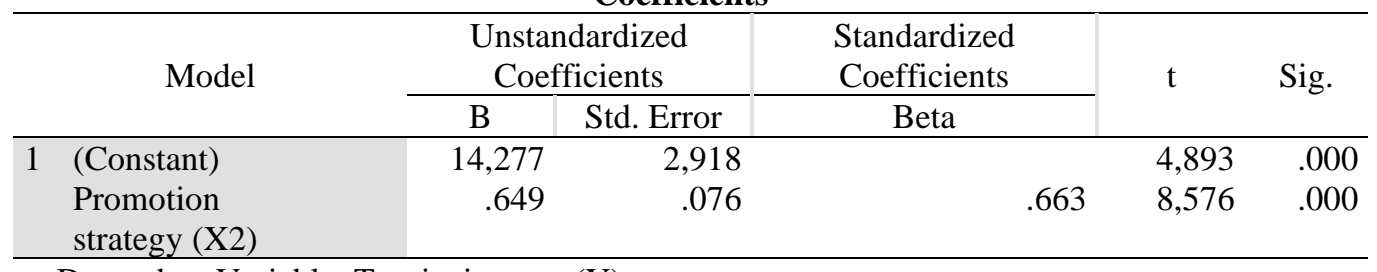

a. Dependent Variable: Tourist interest (Y)

Based on the test results in the table above, the value of tcount $>t$ table or $(8,576>1,986)$ is obtained, thus the second hypothesis that is proposed is that there is a significant influence between promotional strategies on tourist interest is accepted.

\section{Simultaneous Hypothesis Test (Test F)}

Hypothesis testing with the F test is used to determine which simultaneous hypothesis is accepted. The third hypothesis There is a significant influence between guides and promotional strategies on tourist interest.

Table 17. The Result of Guide Hypothesis Test and Promotion Strategy Toward Tourist Interest.

ANOVA a

\begin{tabular}{lrrrrrr}
\hline Model & Sum of Squares & df & Mean Square & F & Sig. \\
\hline $1 \quad$ Regression & 655,576 & 2 & 327,788 & 53,950 & $.000^{\mathrm{b}}$ \\
Residual & 565,049 & 93 & 6,076 & & \\
\multicolumn{2}{l}{ Total } & 1220,625 & 95 & & & \\
\hline Based on the test results in the table above, the calculated $\mathrm{F}$ value> $\mathrm{F}$ table or
\end{tabular}
$(53,950>2,700)$ is obtained, thus the third hypothesis that is proposed that there is a significant influence between guides and promotional strategies on tourist interest is accepted. 


\section{The Influence of Tour Guides on Tourist Interest}

From the analysis, it was found that the guide variable had a significant effect on tourist interest with a correlation value of 0.657 , meaning that the two variables had a strong relationship with the contribution of the influence of $43.2 \%$. Hypothesis testing obtained $t$ value $>\mathrm{t}$ table or $(8,452>1,986)$. Thus the first hypothesis proposed that there is a significant effect between guides on tourist interest is accepted.

\section{The Effect of Promotion Strategy on Tourist Interest}

From the analysis, it was found that the promotional strategy variable had a significant effect on tourist interest with a correlation value of 0.657 , meaning that the two variables had a strong relationship with the contribution of the influence of $43.9 \%$. Hypothesis testing obtained $t$ value> $\mathrm{t}$ table or $(8,576>1,986)$. Thus, the second hypothesis proposed that there is a significant effect between promotional strategies on tourist interest is accepted.

\section{The Influence of Tour Guides and Promotion Strategies on Tourist Interest}

The results of analysis of variables guides and promotional strategies significantly influence the interest of tourists to the regression equation $\mathrm{Y}=9.311+0.372 \mathrm{X} 1+0.406 \mathrm{X} 2$, the value of a correlation of 0.733 means that the two variables have a strong relationship with the contribution of the effect of $53.7 \%$ while the rest of $46.3 \%$ is influenced by other factors. Hypothesis testing obtained the value of $F$ count $>F$ table or $(53,950>2,700)$. Thus, the third hypothesis proposed that there is a significant effect between tour guides and promotion strategies on tourist interest is accepted.

\section{CONCLUSION}

Tour guides have a significant effect on the interest of tourists with a correlation value of 0.657 or strong with an influence contribution of $43.2 \%$. Hypothesis testing obtained the value of $t$ count> $t$ table or $(8,452>1,986)$. Thus, there is a significant influence between tour guides on the interest of tourists visiting Bali. The promotion strategy has a significant effect on tourist interest with a correlation value of 0.657 or strong with an influence contribution of $43.9 \%$. Hypothesis test obtained $t$ value $>t$ table or $(8,576>1,986)$. Thus, there is a significant influence between promotional strategies on the interest of tourists visiting Bali. Tour guides and promotion strategies have a significant effect on tourist interest with a correlation value of 0.733 or strong with an influence contribution of $53.7 \%$ while the remaining $46.3 \%$ is influenced by other factors. Hypothesis test obtained $\mathrm{F}$ count $>\mathrm{F}$ table or $(53,950>2,700)$. Thus, there is a significant influence between the tour guide and the promotion strategy simultaneously on the interest of tourists visiting Bali .

\section{REFERENCES}

Creswell, J. W., \& Clark, V. L. P. (2017). Designing and conducting mixed methods research. Sage publications.

Creswell, J. W., \& Creswell, J. D. (2017). Research design: Qualitative, quantitative, and mixed methods approaches. Sage publications.

Gao, B. W., Zhang, H., \& Decosta, P. L. (2012). Phantasmal destination: A Post-modernist Perspective. Annals of Tourism Research, 39(1), 197-220. https://doi.org/https://doi.org/10.1016/j.annals.2011.06.003

Grissemann, U. S., \& Stokburger-Sauer, N. E. (2012). Customer co-creation of travel services: 
The role of company support and customer satisfaction with the co-creation performance. Tourism Management, 33(6), 1483-1492.

Houge Mackenzie, S., Boudreau, P., \& Raymond, E. (2020). Women's adventure tour guiding experiences: Implications for well-being. Journal of Hospitality and Tourism Management, 45, 410-418. https://doi.org/https://doi.org/10.1016/j.jhtm.2020.09.006

Huerta-Álvarez, R., Cambra-Fierro, J. J., \& Fuentes-Blasco, M. (2020). The interplay between social media communication, brand equity and brand engagement in tourist destinations: An analysis in an emerging economy. Journal of Destination Marketing \& Management, 16, 100413. https://doi.org/https://doi.org/10.1016/j.jdmm.2020.100413

Husain, T., Akib, H., Gani, H. A., \& Guntur, M. (2018a). Collaboration of actor in formulation of development program tourism destination in West Halmahera Regency. (Study In Tuada and Bobanehena Village, Jailolo District) - Indonesia. Espacios, 39(44).

Husain, T., Akib, H., Gani, H. A., \& Guntur, M. (2018b). Collaboration of actor in formulation of development program tourism destination in West Halmahera Regency. (Study In Tuada and Bobanehena Village, Jailolo District) - Indonesia | Colaboración del actor en la formulación del programa de desarrollo del des. Espacios, 39(44).

Malenkina, N., \& Ivanov, S. (2018). A linguistic analysis of the official tourism websites of the seventeen Spanish Autonomous Communities. Journal of Destination Marketing \& Management, 9, 204-233. https://doi.org/https://doi.org/10.1016/j.jdmm.2018.01.007

Muhtasom, A., Ab, A., \& Ab, A. (2019). Kahayya Village as a Priority Destination for Rural Tourism Development Policy in Bulukumba Regency. Jurnal Ad'ministrare, 6(1), 1. https://doi.org/10.26858/ja.v6i1.9432

Pan, Y., Fu, X., \& Youcheng Wang. (2020). How does travel link to life satisfaction for senior tourists? Journal of Hospitality and Tourism Management, 45, 234-244. https://doi.org/https://doi.org/10.1016/j.jhtm.2020.07.013

Papalapu, D. M., Nawawi, J., Tahir, H., \& Akib, H. (2016). The role of the department of social in empowering the street children in Makassar. International Journal of Economic Research, 13(1).

Said, F., Salam, R., Akib, H., \& Baharuddin, A. (2017). An Analysis of Tourism Visit Trend. 149(Icest), 34-36.

Yoeti, O. A. (2010). Dasar-dasar Pengertian Hospitality dan Pariwisata. Bandung: PT. Alumni. 
Wayan Ardani1 et.al., The Effect of Private Visiting and Promotion Strategy ...137 